\title{
Relationship between Personality, Perceived Value and Behavioral Intention of Selected Electronic Brand Customers in Kenya
}

\author{
Kiprop Eric Kibos (Corresponding Author) \\ Moi University, Kenya, School of Business and Economics \\ Department of Marketing and Logistics \\ P.O Box 3900-30100. Eldoret, Kenya \\ E-mail: Kipropkibos@gmail.com \\ Mukoswi Robert Odunga \\ Moi University, Kenya, School of Business and Economics, \\ Department of Finance and Accounting \\ P.O Box 3900-30100. Eldoret, Kenya \\ E-mail: rodunga@mu.ac.ke \\ Kipkirui Daniel Langat \\ The Cooperative University, Kenya, School of Cooperatives and Community Development, \\ Department of Cooperative and Agribusiness Management \\ P.O Box 24814-00502 Karen, Kenya \\ E-mail: dlangat@cuk.ac.ke
}

Received: October 21, 2019

Accepted: November 2, 2019

Published: November 9, 2019

doi:10.5296/rbm.v7i1.15837

URL: http://dx.doi.org/10.5296/rbm.v7i1.15837

\begin{abstract}
The main purpose of the study was to investigate the relationship between perceived value, personality and behavioural intention of consumers of electronic brand in Kenya. The study was guided by: theory of reasoned action, consumption value theory and big five personality traits theory. The study adopted explanatory research design while the target population was 32,567 customers from which a sample of 400 respondents was obtained using multi-stage sampling procedure. Data was collected using questionnaires and analyzed using hierarchical regression. The results revealed that customer perceived brand value $(\beta=.342 ; \mathrm{P}<.000)$ has significant direct influence on behavioural intention of consumers of electronic brands, while perceived sacrifice $(\beta=0.246 ; \mathrm{P}<0.05)$ also has a direct significant influence on behavioural intentions of consumers of electronic brands. The findings further established that customer


personality has significant moderating effect on the relationship between perceived brand value and behavioural intention of consumer of electronic brands $(\beta=0.038 ; \mathrm{P}<.000)$, while having antagonistic moderating influence on the relationship between customer perceived sacrifices and behavioural intention of consumers of electronic brands $(\beta=0.008 ; \mathrm{P}>0.05)$. The main theoretical contribution of the study findings to the body of knowledge is on the effect of perceived sacrifices on behavioural intention and on how customer personality moderates this relationship. To survive and become competitive in the marketplace electronic firms need to focus on offering brands that reflect customer personality and at the same time that offer brand value while focusing on reducing customer perception of sacrifice.

Keywords: Behavioural Intention, Electronic Brands, Perceived Value, Personality

\section{Introduction}

Successful firms are keen to anticipate customers' needs and to delight them with innovative brands, service, processes and procedures so as to ensure that they bond with the enjoyable experience that the firm and its entire customer ecosystem offer (Gallarza \& Saura, 2006). In fact firms focused on achieving market dominance continuously monitor customer behavior so as to respond with offer values that guarantee favourable customer intention (Meng, Shiang-Min, Liang, \& Yang, 2011). Perceived value can be described as the totality of customer perception of the net benefits he/she is receiving versus what she/he is giving up in terms of costs. When the benefit gained are much more than the sacrifices made the customer is prone to behave favourably towards the, while the contrary is also true benefits (Petrick \& Backman, 2002; Chen \& Dubinsky, 2003; Ha \& Jang, 2010; Eggert \& Ulaga, 2002).

In today's competitive marketplace firms need to absolutely impact the behavioural intention of consumers of their brands positively. This will ensure that these customers continue doing business with the firm, pass affirmative word of mouth to other potential customers, recommend brands to friends and relatives and they become tolerant to price changes of the brands. This can only be achieved if firms and marketing executives are able to continously discern what the customers perceive as value in their brand offering and endeavor to exceed these expectations (Petrick \& Backman, 2002). Nevertheless the predisposition of the customers to have an affirmative or adverse perception of value hence behavioural intention appears to be influenced by among others factors such as environmental factors and customer personality traits. Although there seem to be some disagreements among various researchers (Sarker et al., 2013; Luchs \& Mooradian, 2012) on the extent of the influence of personality traits on customer behavioural or purchase intention as some have found evidence of the linkage while others have not.

It is important that marketing managers understand how customers perceive their brand value and how this perception is influenced by customer personality and lead to relevant customer behavior. This is especially important in the retail consumer electronic markets where the competition is intense because of the numbers of market operators and the brands; and the nature of market fragmentation within the sector. Accordingly the electronic marketplace does realize increased customer turnover, undesirable word of mouth, price intolerance, relatively declining volume of purchase per retail firm, recurrent customer swapping and 
above all frequent firm exit and entry. Because of the intensity of rivalry, retail firms focus on immediate survival without consideration of future customer behavioural intention as influenced by their perception of value and personality. Earlier research have not been able offer concrete evidence whether personality is a worthy predictor of customer behavior without any other relevant information about the customers; in fact Mehmet (2012), Kassarjian and Sheffet (1991), Pervin, (1997) and Plummer (2000) criticized the idea of linking personality to all purchase decisions or buying behavior.

\section{Literature Review}

In their study Park et al., (2006) observed that in deciding whether to repurchase a brand or not consumers always consider the extent to which they receive value for money. Ha and Jang (2010) describe customer perceived value as the difference between total benefits and total sacrifices. According to Sheth et al., (1991); Monroe (1990), Lee and Overby (2004) in Lien et al., (2011) customer perceived value is determined by benefits and sacrifices offered by the brand and can be measured using the following dimensions: customer perceived brand, logistical, social and relational values and perceived customer sacrifices.

In their study Sheth et al., (1991) acknowledged that brands contain five main values that customer look for, and these include: functional, social, emotional, epistemic and conditional. Functional value involve the brands' ability or capacity to perform to customers' expectations. Functional value is obtained from the noticeable and concrete features that customers can directly experience when using or consuming the brand. Social value involve the perceived advantages obtained from a brands association with social class, social standing or a specific social group. Affective value can be described as the perceived advantages or value obtained from a brands ability to stimulate intense emotions. Epistemic value can be described as the value obtained from a brand's capability to gratify inquisitiveness, deliver newness, and/or encounter a craving for knowledge. Aesthetic value is described as the advantage obtained from a brand's capability to offer a sense of attractiveness or to improve individual appearance.

Perceived sacrifice relates to what should be surrendered up so that a customer can obtain a particular brand or service (Zeithaml, 1988). According to Monroe (1990), sacrifice in the context of perceived value is described as perceived total costs to the customer, including: purchase price, costs, and post-purchase costs. They are defined from the customer's perspective and include monetary terms and non-monetary terms (Hutchinson et al., 2009; Lapierre, 2000). In a study Gabbott (2004) identifies sacrifices as having three cost aspects: acquisition, consumption and disposal hence they are what the consumers have to give up in obtaining the purchased brands. Zeithaml's (1988) acknowledged that perceived sacrifice is often revealed as an indicator of the perceived value. Wen et al., (2005) revealed that perceived sacrifice has a direct unfavourable impact on perceived value, this implies that low perceived value could be a consequence of high perceived sacrifice, while low perceived sacrifice could bring about high perceived value.

The study is supported by the theory of planned behavior which proposes that the best and surest approach to forecast an individual's behavior is to evaluate his/her behavioral intention. 
In their study Son et al., (2013) observed that behavioural intention is affected by both internal and external factors surrounding an individual. The internal factors consists of an individual's capacity to accomplish a defined behavior, based on his/her knowledge, skills and abilities. The external factor relate to limitations or availability resources such as money, time, or technology that are needed to perform a particular behavior (Taylor \& Todd, 1995). Ang et al., (2015) in their study acknowledge that individuals with less favorable attitude and subjective norm, will unlikely perform the perceived behavioral control over a certain behavior and the behavior intended.

Consumption Value Theory proposes that customers' choice of a brand to purchase is based on the values that he/she seeks to obtain from the brand (Sheth et al., 1991). The consumption values consists of the perceptions of what they would like to obtain in a specific consumption they want to happen in a specific (consumption) condition, in so to achieve a preferred objective relative to particular brand. Consumption value relates to certain consumption purpose that the customer is aiming at achieving from a specific consumption feeling that is in line with their anticipated end- conditions and styles of behavior. Consumption value is produced when the provided performance aligns with the anticipated performance of customers (Sheth, Newman, \& Gross, 1991). The five-factor theory of personality developed by Costa and McRae, (1992) and incorporates five different variables into a conceptual model for describing personality as consisting of: neuroticism, extroversion, agreeableness, openness, conscientiousness. Big five model holds that the ways people think, feel, and interact with others are attributable to individual differences in five personality dimensions; agreeableness, extraversion, conscientiousness, neuroticism, openness to new experiences (Goldberg, 1981; Costa \& McRae, 1992).

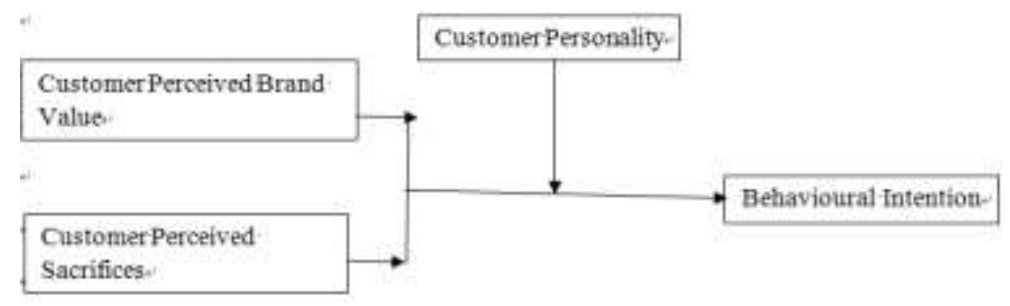

Figure 1. Conceptual Framework

Based on the conceptual framework the study formulated and tested the following hypotheses:

Ho1: There is no relationship between perceived brand value and behavioral intentions of selected electronic brands customers.

Ho2: Customer perceived sacrifices do not affect behavioral intentions of selected electronic brands customers.

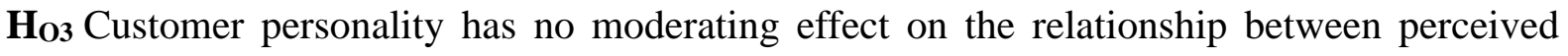
brand value and behavioural intention of selected electronic brands customers. 
Ho10 Customer personality has no moderating effect on the relationship between perceived sacrifices and behavioural intention of selected electronic brands customers.

\section{Method}

The research study used explanatory (causal) research design as it sought to identify causal links between the factors or variables that pertain to the research problem in the study. The target population of the study were retail outlets of electronic brands in Kenya from where the study respondents were drawn. The unit of observation were customers drawn from the retail outlets of the following brands: Huawei, Sony, Samsung Techno, LG, Infinix, HP, Hotpoint, and Lenovo. The study used multistage sampling in obtaining the final sample size of 400 respondents from the target population. The study used structured questionnaires to obtain primary data from the customers of electronic brands. However prior to large-scale administration of the instruments; a pre-testing session was conducted to ensure that the research instrument was devoid of question items which were not relevant to the constructs being measured and to detect any flaws or other weaknesses within the questionnaire design items or variables (Saunders et al., 2007). Pre-test was undertaken using a two-step process. In the first step, the questionnaires were administered to three marketing experts and three randomly picked electronic brand customers to obtain feedback on the suitability of the questionnaire to correctly collect the required data. In the second stage, a field pre-testing of the questionnaire was done. Forty (40) questionnaires were administered to customer drawn from the electronic retail outlets who were not part of the final sample and who were randomly selected. The pilot study responses were analyzed using cronbach alpha with a set lower limit of acceptability of cronbach alpha of 0.7 as recommended by Nunnally (1978). The results indicated that all of the study constructs Cronbach's Alpha coefficients were above the recommended threshold of 0.7 implying that the data collection instrument was reliable. The questionnaire was administered to respondents systematically selected (second (2) customer entering each of the selected electronics retail shops as a starting member). Thereafter the study used hierarchical regression to analyze the data collected so as to establish relationship between independent, moderating and dependent variables.

\section{Results}

\subsection{Correlation Analysis}

Table 1. Correlation Analysis

\begin{tabular}{lllll}
\hline & CBI & CPBV & CPS & CP \\
\hline Customer Behavioural Intention & 1 & & & \\
Customer Perceived Brand Value & $.393^{* *}$ & 1 & & \\
Customer Perceived Sacrifices & $.261^{* *}$ & $.115^{*}$ & 1 & \\
Personality & $-.033^{* *}$ & $.140^{*}$ & $.154^{* *}$ & 1 \\
\hline
\end{tabular}

CBI- Customer Behavioural Intention; CPBV- Customer Perceived Brand Value; Customer Perceived Sacrifices, CP- Customer Personality. 
Pearson correlation coefficients were used to establish the relationships between predictor variables (customer perceived brand, and sacrifices), moderating variable (customer personality), and the criterion variable (customer behavioural intention). Results on table 1 above show that there is significant correlation between customer perceived: brand value and sacrifices; customer personality and customer behavioural intention. The implication of the study results is that there is significant relationship between customer perceived brand value, perceived sacrifices, customer personality and behavioural intention of electronic brand customers.

\subsection{Hypothesis Testing}

The testing of the influence of the study variables was done at two levels: direct and indirect effect. Thus the study sought to establish the direct relationship between perceived value and behavioural intention of electronic brands customers, the indirect effect between perceived value and behavioural intention through the moderating influence of customer personality.

Table 2. Regression Coefficients

\begin{tabular}{lllll}
\hline & Model I & Model II & Model III & Model IV \\
\hline (Constant) & $3.249^{*}$ & $1.018^{*}$ & $1.248^{*}$ & $0.427^{*}$ \\
Age bracket & $.082^{*}$ & $.103^{*}$ & $.098^{*}$ & $.096^{*}$ \\
Annual income bracket & -.055 & $-.081^{*}$ & $-.082^{*}$ & $-.081^{*}$ \\
Highest level of education & .054 & .046 & .041 & .043 \\
Perceived Brand Value (PBV) & & $.342^{*}$ & $.352^{*}$ & $.321^{*}$ \\
Customer Perceived Sacrifice (CS) & & $.246^{*}$ & $.260^{*}$ & $.265^{*}$ \\
Customer Personality (P) & & & $-.091^{*}$ & $-.119^{*}$ \\
P x CPBV & & & & $.038^{*}$ \\
P x CPS & & & & .008 \\
F & 3.366 & 16.568 & 15.338 & 10.544 \\
$\mathrm{R}^{2}$ & .045 & .318 & .328 & .329 \\
Adjusted R & .031 & .299 & .306 & .298 \\
$\Delta \mathrm{R}^{2}$ & .045 & .274 & .010 & .002 \\
Sig. F Change $(\mathrm{P}<0.05)$ & .010 & .000 & .045 & .006 \\
Note: * P<0.05 & & & & \\
\hline
\end{tabular}

Dependent Variable: Customer Behavioural Intention. Predictors: PBV- Customer Perceived Brand Value; CPS- Customer Perceived Sacrifices; CP- Customer Personality.

Ho1: There is no relationship between customer perceived brand value and behavioral intentions of customer of selected electronic brands.

The analysis results displayed in Table 2 of model II show that customer perceived brand value is statistically significant in predicting customer behavioural intention as evidenced by the result of the analysis which show positive unstandardized coefficient implying that 
customer perceived brand value influence customer behavioural intention. Arising from this findings the study rejected the stated null hypothesis and accepted the alternative hypothesis that there is relationship between perceived brands value and behavioral intentions of consumers of electronic brands.

Ho2: Customer perceived sacrifices do not affect behavioral intentions of customer of selected electronic brands.

The analysis results displayed in Table 2 model II show that customer perceived sacrifices value is statistically significant in predicting customer behavioural intention. This is supported by the study positive unstandardized coefficients meaning that customer perceived sacrifices influence customer behavioural intention. These findings led to the rejection of the stated null hypothesis with $95 \%$ confidence level and acceptance of the alternative hypothesis that there is a relationship between customer perceived sacrifices value and behavioral intention of electronic brands consumers.

H03: Customer personality has no moderating effect on the relationship between perceived brand value and behavioural intention of customers of selected electronic brands.

The results shown on model IV in table 2 indicate the interaction effect between customer personality, customers perceived brand value, and customer behavioural intention accounted for significantly more variance and positive unstandardized coefficient. This implied the presence of potentially positive significant moderation effect of customer personality on the relationship between customers' perceived brand value and customer behavioural intention.

H04: Customer personality has no moderating effect on the relationship between perceived sacrifices and behavioural intention of customers of selected electronic brands.

The results in Table 2 Model IV show that the interaction effect of customer personality on customers' perceived sacrifices and customer behavioural intention is not significant as evidenced by unstandardized coefficients. This meant that that there is no potentially significant moderating effect of personality on the relationship between perceived sacrifices and behavioural intention of electronic brand customers. From the findings it can be deduced that when personality is introduced into the relationship between customer perceived sacrifice value and behavioural intention of the electronic brand customers, the relationship which was hitherto significant in Model II shown in Table 2 becomes insignificant meaning that customer personality reverses the potentially significant effect of perceived sacrifices on behavioural intention of electronic brand customers earlier established.

\section{Conclusion and Recommendations of the Study}

Perceived brand value has a direct effect on customer behavioural intention, while customer personality has a moderating effect on the relationship between perceived brand value and the behavioural intention of electronic brand customers. Customers perceived sacrifices has a direct positive significant influence on behavioural intentions of electronic brand customers. However when customer personality is introduced into the relationship between perceived value and behavioural intention of electronic brand customers, the relationship becomes insignificant. 
The main theoretical contribution of the study findings to the body of knowledge is on the effect of perceived sacrifices on behavioural intention and on how customer personality moderates this relationship. Customers' perceived sacrifices in the context of perceived total costs to the customer, relative to total benefits all have a direct positive significant influence on behavioural intentions of electronic brand customers. However when customer personality is introduced into the relationship between perceived value and behavioural intention of electronic brand customers, the relationship becomes insignificant. This means that customer personality has antagonistic effect on the relationship between customer perceived sacrifices and behavioural intention of electronic brand customers as they reduce the direct effect of this direct relationship. To survive and become competitive in the marketplace electronic firms need to focus on offering brands that reflect customer personality and at the same time that offer brand value-brand performance, innovation and social, epistemic, aesthetic and emotional values while focusing on reducing customer perception of sacrifice.

\section{References}

Bagozzi, R. P. (1992). The self-regulation of attitudes, intentions and behavior. Social Psychology Quarterly, 55(June), 178-204

Bobbitt, L. M. (2004). An Examination of the Logistics Leverage Process: Implications for Marketing Strategy and Competitive Advantage. Unpublished Ph.D. Dissertation, University of Tennessee.

Cattell, R. B. (1945). The principle trait clusters for describing personality. Psychological Bulletin, 42, 129-161.

Costa Jr, P. T., Mccrae, R. R., \& Dye, D. A. (1991). Facet Scales for Agreeableness and Conscientiousness: A Revision of the Neo Personality Inventory. Personality and Individual Differences, 12(9), 887-898

Costa, P. T., \& McCrae, R. R. (1985). The NEO Personality Inventory Manual. Odessa, FL: Psychological Assessment Resources

Day, G. D. (1990). The Capabilities of Market-Driven Organizations. Journal of Marketing, $58,37-52$.

Eysenck, H. J. (1952). The scientific study of personality. Oxford, England: Macmillan.

Eysenck, H. J. (1991). Dimensions of personality: 16, 5, or 3?--Criteria for a taxonomic paradigm. Personality and Individual Differences, 12, 773-790.

Fishbein, M., \& Ajzen, I. (1975). Belief, attitude, intention, and behavior: An Introduction to Theory and Research. Reading, MA: Addison-Wesley

Gallarza, M. G., \& Saura, I. G. (2006). Value dimensions, Perceived Value, Satisfaction and Loyalty: An investigation of university students' travel behaviour. Tourism Management, 27(3), 437-452

Goldberg, L. R., \& Rosolack, T. K. (1994). The Big Five factor structure as an integrative framework: An empirical comparison with Eysenck's P-E-N model. In C. F. Halverson, 
G. A. Kohnstamm, \& R. P. Martin (Eds.), The developing structure of temperament and personality from infancy to adulthood. Hillsdale, NJ: Lawrence Erlbaum Associates.

Hutchinson, J., Lai, F., \& Wang, Y. (2009). Understanding the relationships of quality, value, equity, satisfaction, and behavioral intentions among golf travelers. Tourism Management, 30, 298-308

Kassarjian, H. H., \& Sheffet, J. M. (1991). Personality and Consumer Behavior. An Update. In H. H. Kassarjian \& T. S. Robertson (Eds.), Handbook of Consumer Behavior (4th ed., 281-303). Englewood Cliffs, N.J. Prentice- Hall International Edition

Keller, K. L., \& Kotler, P. (2009). Marketing Management. Upper Saddle River, N.J.: Pearson Prentice Hall.

Lai, W.-T., \& Chen, C.-F. (2011). Behavioral intentions of public transit passengers: The roles of service quality, perceived value, satisfaction and involvement. Transport Policy, 18, 318-325.

Lapierre, J. (2000). Customer-Perceived Value in Industrial Contexts. The Journal of Business \& Industrial Marketing, 15(2/3), 122-139.

Lee, M. C., \& Hwan, I. S. (2005). Relationships among service quality, customer satisfaction and profitability in the Taiwanese banking industry. International Journal of Management, 22(4), 635-648.

Lien, C. H., Wen, M. J., \& Wu, C. C. (2011). Investigating the relationships among e-service quality, perceived value, satisfaction, and behavioural intentions in Taiwanese online shopping. Asia Pac. Manag. Rev., 16, 211-223.

Liu, F., Zhao, X., Chau, P. Y., \& Tang, Q. (2015). Roles of perceived value and individual differences in the acceptance of mobile coupon applications. Internet Res., 25, 471-495.

Luchs, M. G., \& Mooradian, T. A. (2012). Sex, Personality, and Sustainable Consumer Behavior: Elucidating the Gender Effect. Journal of Consumer Policy, (35), 127-144.

Mehmet, M. (2012). Personality effects on experiential consumption. Elsevier Journal, Norway, 52, 94-98.

Meng, S.-M., Liang, G. S., \& Yang, S. H. (2011). The Relationships of Cruise Image, Perceived Value, Satisfaction, and Post-Purchase Behavioral Intention on Taiwanese Tourists. African Journal of Business Management, 5(1), 19-29.

Monroe, K. B. (1990). Pricing: Making Profitable Decisions. New York: McGraw-Hill.

Nunnally, J. C. (1978). Psychometric theory (2nd ed.). New York, NY: McGraw Hill.

Pervin, L. (1997). Personality: Theory and Research (7th ed.). New York, USA, John Wiley and Sons, Inc.

Petrick, J., \& Backman, S. (2002). Examination of the construct of perceived value for the Prediction of Golf Travelers; Intentions to revisit. Journal of Travel Research, 41, 38-45. 
Picazo-Vela, S., Chou, S. Y., Melcher, A. J., \& Pearson, J. M. (2010). Why Provide an Online Review? An Extended Theory of Planned Behavior and the Role of Big-Five Personality Traits. Computers in Human Behavior, 26, 685-696

Plummer, J. T. (1974). Concept and application of lifestyle segmentation. Journal of Marketing, 38(1), 33-37.

Ranjbarian, K., \& Kia, M. (2010). The Influence of Personality Traits on Consideration Set Size. European Journal of Social Sciences, 15(2), 127-42.

Roccas, S., Sagiv, L., Schwartz, S. H., \& Knafo, A. (2002). The Big Five Personality Factors and Personal Values. Personality and Social Psychology Bulletin, 28, 789-801.

Santonen, T., Kaivo-oja, J., \& Suomala, J. (2007). Introduction to National Open Innovation System (NOIS) Paradigm. A Preliminary Concept for Interchange, FFRC eBooks 8/2007.

Sarker, S. B., Palit, T. K., \& Haque, E. M. (2013). Influence of Personality in Buying Consumer Goods-A Comparative Study Between Neo-Freudian Theories And Trait Theory Based On Khulna Region. International Journal of Business and Economics Research, 2(3), 41-58.

Schiffman, L. G., \& Kanuk, L. (2008). Consumer Behavior. NY, Prentice Hall.

Sheth, J. N., Newman, B. I., \& Gross, B. L. (1991). Why we buy what we buy: A theory of Consumption values. Journal of Business Research, 22, 159-70.

Tsao, W. C., \& Chang, H. R. (2010). Exploring the Impact of Personality Traits on Online Shopping Behavior. African Journal of Business Management, 4(9), 1800-1812.

Ulaga, W. (2003). Capturing Value Creation in Business Relationships: A Customer Perspective. Industrial Marketing Management, 32, 677-93.

Zeithaml, V. A. (1988). Consumer Perceptions of Price, Quality and Value: A Means-End Model and Synthesis of Evidence. Journal of Marketing, 52, 2-22.

Zeithaml, V. A., Berry, L. L., \& Parasuraman, A. (1991). Refinement and Reassessment of The SERVQUAL Scale. Journal of Retailing, 67(4), 420-450.

\section{Copyright Disclaimer}

Copyright reserved by the author(s).

This article is an open-access article distributed under the terms and conditions of the Creative Commons Attribution license (http://creativecommons.org/licenses/by/3.0/). 